\title{
EFEKTI DOBI NA MEĐUSOBNI ODNOS VERBALNIH I NEVERBALNIH SPOSOBNOSTI TE EMOCIONALNE INTELIGENCIJE
}

\author{
Dario Vučenović \\ Hrvatski studiji Sveučilišta u Zagrebu \\ Kampus Borongaj, Borongajska cesta 83d, 10000, Zagreb \\ dvucenovi@hrstud.hr \\ Ljerka Hajncl \\ Zavod za vještačenje, profesionalnu rehabilitaciju i zapošljavanje osoba s invaliditetom \\ Područni ured Osijek, Tadije Smičiklasa 2, 31000 0sijek \\ ljerka.hajncl@os.ht.hr
}

\begin{abstract}
Sažetak
Provedenim istraživanjem nastojao se utvrditi međusobni odnos rezultata mjerenja emocionalne inteligencije, njihove relacije $s$ mjerom verbalnih i neverbalnih sposobnosti te dobi i spola sudionika. Ispitivanje je provedeno na uzroku od 500 sudionika, širokog raspona kronološke dobi (od 15 do 65 godina; prosjek 36,9 godina) te oba spola $(\mathrm{M}=257 ; \breve{Z}=243)$. Dobivena je značajna povezanost varijabli emocionalne inteligencije te spola i dobi sudionika. Drugim riječima, žene i stariji sudionici imaju više razine emocionalne inteligencije. Dob je povezana s višim rezultatima emocionalne inteligencije, a negativna je povezanost utvrđena između neverbalne inteligencije i dobi, odnosno u starijim dobnim skupinama uočene su značajno niže razine neverbalnih sposobnosti. Ključni nalaz odnosi se na činjenicu kako s dobi i iskustvom dolazi do poboljšanja rezultata na mjeri emocionalne inteligencije, posebno na složenijim granama kao što su razumijevanje i analiza emocija te refleksivnost i regulacija emocija. Navedeni rezultati te dobivene korelacije s verbalnim faktorom inteligencije, doprinose potvrdi tumačenja emocionalne inteligencije kao sposobnosti nasuprot stajalištu kako se radi o osobini ličnosti koja bi se trebala mjeriti skalama samoprocjene.
\end{abstract}

Ključne riječi: verbalne i neverbalne sposobnosti, emocionalna inteligencija.

\section{UVOD}

Pojava konstrukta emocionalne inteligencije omogućila je sustavno istraživanje procesa u pozadini obrade emocionalnih informacija. Emocionalna inteligencija uključuje sposobnost zapažanja, procjene i izražavanja emocija; sposobnost uviđanja 
i generiranja osjećaja koji olakšavaju mišljenje; sposobnost razumijevanja emocija i znanje o emocijama te sposobnost reguliranja emocija u svrhu promocije emocionalnog i intelektualnog razvoja (Mayer i Salovey, 1997). Četiri navedene skupine sposobnosti poredane su, prema složenosti psihičkih procesa, od jednostavnijih (zapažanje i izražavanje emocija) do složenijih (svjesnost, refleksivnost i regulacija emocija). Petrides i Furnham (2000) predložili su distinkciju između dva različita konstrukta. Emocionalna inteligencija kao osobina ličnosti predstavlja skup samopercepcija i dispozicija povezanih s emocijama. Proučava se u okviru psihologije ličnosti, a mjeri skalama samoprocjene vlastitih emocionalnih sposobnosti. Zbog poznatih nedostataka metode samoprocjene (davanje poželjnih odgovora, nepoznavanje vlastitih emocionalnih stanja i nemogućnost adekvatne procjene) te veće sličnosti s klasičnim načinima ispitivanja inteligencije, u novije vrijeme naglašava se važnost pristupa ispitivanju emocionalne inteligencije kao sposobnosti. To se odnosi na stvarnu sposobnost percipiranja, procesiranja i korištenja emocionalnih informacija. Budući da se tako definirana uklapa u područje kognitivnih sposobnosti, mjeri se testovima maksimalnog učinka.

Roberts, Zeidner i Matthews (2002) navode kako se u teoriju o fluidnoj i kristaliziranoj inteligenciji može uklopiti objašnjenje za konstrukt emocionalne inteligencije. Naime, oni smatraju kako emocionalna inteligencija čini dio kristalizirane inteligencije, a tu tvrdnju potkrepljuju mišljenjem da se procjena, ekspresija, regulacija i korištenje emocija razvijaju kroz iskustvo i socijalnu interakciju na isti način kao i drugi psihološki procesi koji čine kristaliziranu inteligenciju. U novije vrijeme, temeljem sve većeg broja istraživanja, uočava se napredak u teorijskom usavršavanju konstrukta emocionalne inteligencije, konstrukciji i provjeri instrumentarija te se dobiva sve bolji uvid u samu prirodu procesiranja emocionalnih sadržaja i praktičnu primjenu u rješavanju svakodnevnih problema. Autori pokušavaju pronaći mjesto konstruktu u prostoru različitih teorija inteligencije i osobina ličnosti pa tako Roberts i sur. (2001) te Vučenović (2012) navode podatak kako mjere emocionalne inteligencije uglavnom korespondiraju s mjerama kristalizirane inteligencije, odnosno onim dijelom kognitivnih sposobnosti koji se razvija s iskustvom. U prilog tome govore i pozitivne korelacije s postojećim verbalnim testovima inteligencije (Lopez, Salovey i Straus, 2003). Kako bismo potvrdili hipotezu o emocionalnoj inteligenciji kao sposobnosti, važno je dokazati nekoliko različitih kriterija: razvojni kriterij (promjene po dobnim skupinama), konceptualni (postojanje određenog mentalnog učinka) i korelacijski (značajne ali ne previsoke korelacije s mentalnim sposobnostima, a najviše s verbalnim faktorom). Navedeni kriteriji svrstavaju emocionalne kompetencije u kategoriju mentalnih sposobnosti. Pretpostavka brojnih autora (Slaski i Cartwright, 2003; Vučenović 2009; 2012) je da se emocionalna inteligencija može razvijati u funkciji dobi i iskustva pojedinca. Navedena pretpostavka rezultirala je povećanim interesom istraživača za ovo područje. U posljednje vrijeme počela je intenzivnija primjena programa koji imaju za cilj razvijanje socijalnih i emocionalnih vještina kao što su vještine adekvatnog rješavanja problema, 
donošenja odluka, poboljšanja komunikacijskih vještina, prepoznavanja vlastitih i tuđih emocija, regulacija emocija i upravljanja vlastitim ponašanjem (Vučenović, 2015; Vučenović, Hajncl i Takšić, 2015). Osnovni cilj takvih programa je učiniti osobe otpornijima na razne psihopatološke probleme poput depresivnosti, delinkvencije, nasilja ili zlouporabe droga te podići razinu kvalitete socijalne podrške i zadovoljstvo životom.

Bez obzira na određene različitosti u pristupu konceptu emocionalne inteligencije, dvije su zajedničke pretpostavke o EI. Kao prvo, procesiranje emocionalnih informacija je drugačije prirode i relativno neovisno o sposobnostima koje se vezuju uz tradicionalno shvaćanje inteligencije. Također, emocionalna inteligencija je posebna vrsta sposobnosti, a ne sustav preferiranih ponašanja. Kao takva, ona je važna determinanta uspjeha u mnogim područjima života, koja može biti važnija i od klasične inteligencije (Goleman, 1997; Kulenović, Balenović i Buško, 2001). Razvojna komponenta emocionalne inteligencije nije bila obuhvaćena dosadašnjim istraživanjima, a pokazala se kao vrlo bitna osnova za primjenu različitih intervencijskih programa za razvoj emocionalne inteligencije čija uspješnost i opravdanost, može se pretpostaviti, ovisi upravo o mogućnostima njezina rasta i razvoja. Naime, istraživanja spolnih i dobnih razlika u emocionalnoj inteligenciji nisu na adekvatan način i u potpunosti obuhvatila dobne razlike u emocionalnoj inteligenciji. Najčešće se radilo o istraživanjima koja su provedena na djeci i adolescentima (Ivanović, 2008; Vučenović, 2009; Cauffman i sur., 2010; Leclerc i Kensinger, 2011).

Slijedom prethodno navedenih postavki cilj je bio ispitati dobne i spolne razlike u emocionalnoj inteligenciji i njezin odnos s mjerom verbalnih i neverbalnih sposobnosti te istražiti razlike s obzirom na spol sudionika, od adolescencije do kasne odrasle dobi.

\section{METODA}

\section{Sudionici i postupak}

Istraživanjem su bili obuhvaćeni sudionici širokog raspona kronološke dobi, od 15 do 65 godina. U istraživanju je sudjelovalo ukupno 500 osoba koje su, sukladno transverzalnom nacrtu, podijeljene u različite dobne skupine. Istraživanje se provodilo na manjim skupinama zbog lakše primjene testova i bolje kontrole, a sudionicima je osigurana anonimnost.Prije početka testiranja ukratko im je objašnjena svrha istraživanja i način provedbe ispitivanja. Naglašeno je da će se prikupljeni podaci koristiti isključivo u znanstvene svrhe, te da se njihova privatnost štiti sukladno etičkim principima. Dodatno, za maloljetnike je zatražena suglasnost roditelja. Neposredno prije same primjene, sudionicima je pročitana uputa za svaki mjerni instrument, a dodatna objašnjenja su im pružana individualno ako je bilo opravdano i potrebno. Ukupno trajanje testiranja kretalo se od dva do tri sata, ovisno o dobi. 
Instrumenti

\section{Cattellov test inteligencije}

Cattellov neverbalni test inteligencije, skraćeno CTI (Cattell, 2000), mjeri tzv. g. faktor i smatra se jednim od kulturalno nepristranih testova. Može se primjenjivati pojedinačno ili grupno, a zadatak ispitanika je uočavanje i zaključivanje o odnosima između različitih oblika i slika. Cattellovi testovi inteligencije imaju tri različite ljestvice. Ljestvica 1 konstruirana je za djecu od 4 do 8 godina, dok se ljestvice 2 i 3 mogu koristiti za stariju djecu i odrasle ispitanike. Ljestvica 2 omogućava bolje razlikovanje ispitanika u rasponima prosječne inteligencije, zbog čega je korištena $u$ ovom heterogenom uzorku. Sadrži ukupno 46 čestica, podijeljenih u četiri subtesta (nizovi - 12 čestica, klasifikacije - 14 čestica, matrice 12 - čestica i uvjeti ili topologija - 8 čestica). Pouzdanost Cattellova testa (Ljestvica 2) kreće se u rasponima od 0,67 do 0,84 . Također, utvrđena je visoka konstruktna valjanost (korelacija s g-faktorom inteligencije od 0,81 do 0,85 ) i visoka kriterijska valjanost (korelacije od 0,70 do $0,77 \mathrm{~s}$ drugim testovima opće inteligencije). U ovom istraživanju dobiven je zadovoljavajući Cronbach alpha koeficijent pouzdanosti $(0,73)$.

\section{DAT - baterija općih sposobnosti - verbalno rasuđivanje}

DAT-baterija općih sposobnosti omogućuje procjenu tri različita područja: verbalno rasuđivanje, numeričko rasuđivanje i apstraktno rasuđivanje. Test verbalnog rasuđivanja, koji je korišten u ovom istraživanju, mjeri sposobnost razumijevanja odnosa među riječima. Sastoji se od 40 čestica-analogija, a u svakoj analogiji nedostaju dvije riječi. Zadatak ispitanika je da izabere jedan od ponuđenih odgovora koji će na ispravan način dopuniti tvrdnju i učiniti je smislenom. Koeficijenti pouzdanosti DAT testova kreću se u rasponu od 0,80 do 0,90 prema najnovijoj europskoj standardizaciji (Hyde i Trickey, 2005). Pouzdanost testa verbalnog rasuđivanja manja je nego kod druga dva testa i kreće se od 0,72 do 0,77 , a u ovom istraživanju Cronbach alpha koeficijent pouzdanosti iznosi 0,68.

\section{Mayer-Salovey-Caruso Emotional Intelligence Test - MSCEIT}

MSCEIT je druga baterija testova istih autora koji je otklonio nedostatke svog prethodnika (MEIS) i unaprijedio njihov model EI (Mayer, Salovey i Caruso, 2002). Dugo vremena bio je jedini publicirani test emocionalne inteligencije u svijetu (Takšić, Mohorić i Munjas, 2006). MSCEIT procjenjuje emocionalnu inteligenciju na sličan način kao i klasični testovi inteligencije (Mayer, Salovey, Caruso i Sitarenios, 2003). Sadržava osam subskala, po dvije iz svake od četiri skupine sposobnosti: percepcija i izražavanje emocija, korištenje emocija kao pomoć u mišljenju, razumijevanje i analiziranje emocija, reflektivno upravljanje emocija- 
ma. U ovom ispitivanju korištene su subskale D i H koje se odnose na dimenziju reflektivnog upravljanja emocijama. MSCEIT je standardiziran na oko 5000 ispitanika, a podaci su prikupljeni na reprezentativnom uzorku. Pouzdanost svake od četiri subskale kreću se od 0,86 do 0,93. Provjeravajući konvergentno-divergentnu valjanost MSCEIT-a, dobivene su pozitivne korelacije s poznatim testovima inteligencije u rasponu od 0,03 do 0,35 . Prilikom određivanja točnog odgovora primijenjene su metode mod i prošireni mod, a Cronbach alpha koeficijent pouzdanosti u ovom istraživanju iznosi je 0,59 .

Podaci su prikupljeni u sklopu znanstvenog projekta pod nazivom Razvoj $i$ kroskulturalna provjera konstrukta emocionalne inteligencije (MB: 009-03426182657) pod vodstvom prof. dr. sc. Vladimira Takšića. Cilj Projekta bio je validirati dosada konstruirane, ali i razviti nove znanstveno utemeljene instrumente za empirijsku provjeru konstrukta emocionalne inteligencije. Projekt je u razdoblju od 2002. do 2005. godine financiralo MZOŠ u okviru kojeg je formiran međunarodni tim stručnjaka. Validacija mjernih instrumenata, između ostalog, bazirala se i na dopuštenju autora MSCEIT-a za njegovo korištenje u znanstvene, ne i komercijalne svrhe.

\section{REZULTATI}

$\mathrm{Na}$ početku prikaza dobivenih rezultata istraživanja, u Tablici 1 prikazane su prosječne vrijednosti i raspršenja rezultata svih ispitivanih varijabli, zatim Kolmogorov-Smirnovljev test značajnosti odstupanja od normalne distribucije, prosječne korelacije među česticama te Cronbach alpha koeficijenti pouzdanosti za sve varijable korištene u istraživanju $(N=500)$.

Kao što se može vidjeti iz Tablice 2, dobivene su statistički značajne povezanosti između rezultata na Cattellovu neverbalnom testu inteligencije (CTI) i serije DAT-verbalno rasuđivanje, kao i rezultata na MSCEIT-u te spola i dobi sudionika. Dobiveni nalazi potvrđuju pretpostavke o tome kako je emocionalne inteligencija

Tablica 1. Osnovni statistički parametri $(N=500)$

\begin{tabular}{lcccccccccc}
\hline Var & $N$ & $M$ & Min & Max & Raspon & $S d$ & KS & $p$ & $r$ & Cronbach $\alpha$ \\
\hline CTI & 500 & 31,16 & 15 & 45 & 30 & 4,83 & 1,62 &, 101 & 0,052 & 0,73 \\
DAT-VR & 500 & 19,80 & 5 & 35 & 30 & 5,03 & 1,45 &, 318 & 0,051 & 0,68 \\
MSCEIT & 500 & 22,34 & 10 & 29 & 19 & 3,22 & 3,19 &, 000 & 0,052 & 0,59 \\
Dob & 500 & 37,00 & 15 & 65 & 50 & 15,03 & - & - & - & - \\
\hline
\end{tabular}

Legenda: CTI - Cattellov neverbalni test inteligencije; DAT - DAT baterija, skala Verbalno rasuđivanje; EI - Mayer-Salovey-Caruso Emotional Intelligence Test (MSCEIT) 
Tablica 2. Korelacije između ispitivanih varijabli $(N=500)$

$\begin{array}{lccccc} & \text { Cattell } & \text { DAT-VR } & \text { MSCEIT } & \text { Spol } & \text { Dob } \\ \text { CTI } & 1,00 & & & \\ \text { DAT-VR } & 0,53^{*} & 1,00 & & \\ \text { MSCEIT } & 0,01 & 0,03 & 1,00 & & \\ \text { Spol } & -0,09 & -0,07 & 0,29 * & 1,00 & \\ \text { Dob } & -0,34^{*} & -0,02 & 0,11^{*} & -0,01 & 1,00 \\ * p<, 05 & & & & & \end{array}$

povezana s dobi i iskustvom, dok negativna povezanost fluidne inteligencije i dobi upućuje na opadanje neverbalnih sposobnosti nakon adolescencije.

Ispitivanje dobnih i spolnih razlika u rezultatima

Drugi problem ovog istraživanja bio je ispitati postoje li razlike u rezultatima postignutim na mjerama emocionalne inteligencije, te verbalnih i neverbalnih sposobnosti s obzirom na dob i spol sudionika, korištenjem metode dvosmjerne analize varijance.

Kao što se može vidjeti na Slici 1, prosječne vrijednosti rezultata na MSCEIT-u variraju s obzirom na spol i dob. Može se reći da su kod žena emocionalne sposobnosti izraženije u periodu nakon adolescencije, dosežu vrhunac oko 30. godine života, nakon čega je vidljiv lagani pad ili pak stagnacija vrijednosti. Muškarci postižu maksimalne vrijednost tek u dobnoj skupini 41-50 godina života, dok u starijim dobnim skupinama nije zabilježen značajniji pad. Također, razlike između žena i muškaraca veće su kod mlađih dobnih skupina.

S obzirom da dobiveni rezultati pokazuju značajne razlike u svim dobnim skupinama, može se zaključiti kako žene općenito imaju razvijenije emocionalne sposob-

Tablica 3. Struktura sudionika s obzirom na kronološku dob i spol

\begin{tabular}{lcccc}
\hline Dobna skupina & Prosječna dob & M & Ž & $N$ \\
\hline $15-20$ & 17,7 & 44 & 56 & 100 \\
$21-30$ & 26,5 & 54 & 47 & 101 \\
$31-40$ & 36,4 & 44 & 50 & 94 \\
$41-50$ & 45,7 & 52 & 54 & 106 \\
50 i više & 58,2 & 49 & 50 & 99 \\
\hline Ukupno & - & 243 & 257 & 500 \\
\hline
\end{tabular}




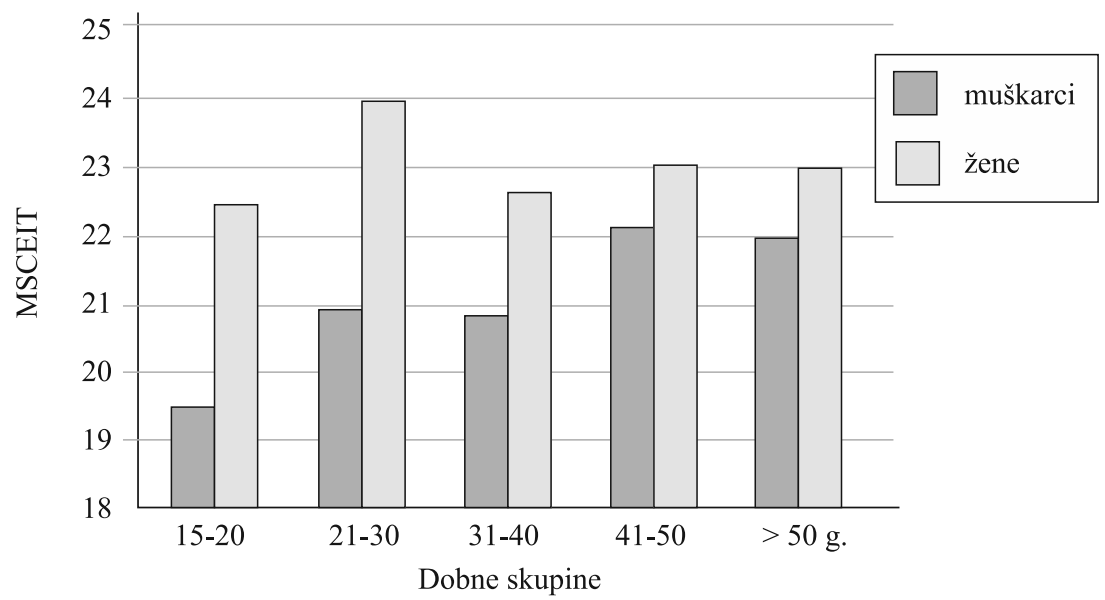

Slika 1. Prikaz prosječnih rezultata na MSCEIT-u s obzirom na dob i spol $(N=500)$

Tablica 4. Razlike u mjerenju emocionalne inteligencije s obzirom na dob i spol $(N=500)$

\begin{tabular}{lcrc}
\hline MSCEIT & $d f$ & \multicolumn{1}{c}{$F$} & \multicolumn{1}{c}{$p$} \\
\hline Spol & 1 & 51,00 & 0,000 \\
Dob & 4 & 5,00 & 0,001 \\
spol $\times$ dob & 4 & 3,00 & 0,019 \\
\hline
\end{tabular}

nosti od muškaraca. Interakcija dobi i spola također je značajna budući da su žene iz svih dobnih skupina postizale značajno bolje rezultate na MSCEIT-u od skupine najmlađih muškaraca (15 do 20 godina), a mlađi muškarci postizali su značajno lošije rezultate od starijih.

Razlike u prosječnim vrijednostima rezultata postignutih na CTI-u s obzirom na dob i spol sudionika prikazana su na Slici 2. Ukupno gledajući, i žene i muškarci iz mlađih dobnih skupina postigli su značajno bolje rezultate od muškaraca i žena starije dobi, a prosječni rezultati žena i muškaraca pokazuju niže vrijednosti u starijim dobnim skupinama. Razlika između muškaraca i žena gotovo da je zanemariva u prvoj (15-20) i zadnjoj dobnoj skupini (iznad 50 godina), dok u svim ostalim skupinama muškarci u pravilu postižu bolje rezultate.

Kao što možemo vidjeti iz Tablice 5, dobivene su statistički značajne razlike između rezultata postignutih na Cattellovu testu inteligencije s obzirom na spol i dob sudionika. Kao što je očekivano, muškarci su postigli bolje rezultate na neverbalnom testu inteligencije od žena, dok u isto vrijeme mlađi sudionici postižu bolje rezultate od starijih. 


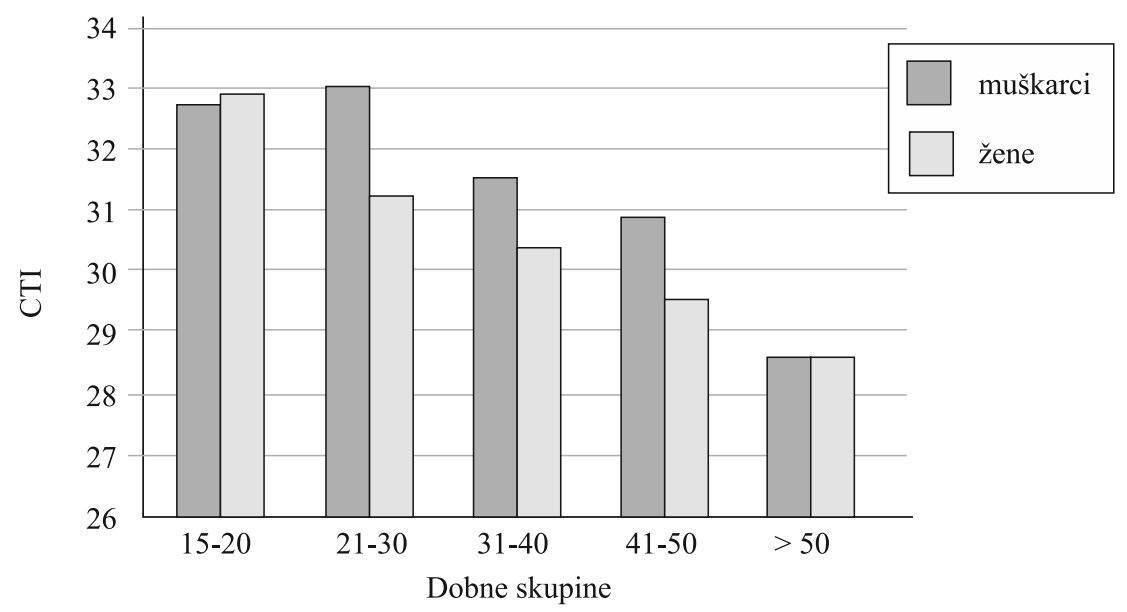

Slika 2. Prikaz prosječnih vrijednosti rezultata na Cattellovu testu inteligencije (CTI) s obzirom na dob i spol sudionika $(N=500)$

Tablica 5. Prikaz razlika između rezultata dobivenih na Cattellovu neverbalnom testu inteligencije s obzirom na dob i spol sudionika $(N=500)$

\begin{tabular}{lcrc}
\hline CTI & $d f$ & $F$ & $p$ \\
\hline Spol & 1 & 4,43 & 0,036 \\
Dob & 4 & 13,70 & 0,000 \\
spol $\times$ dob & 4 & 0,97 & 0,422 \\
\hline
\end{tabular}

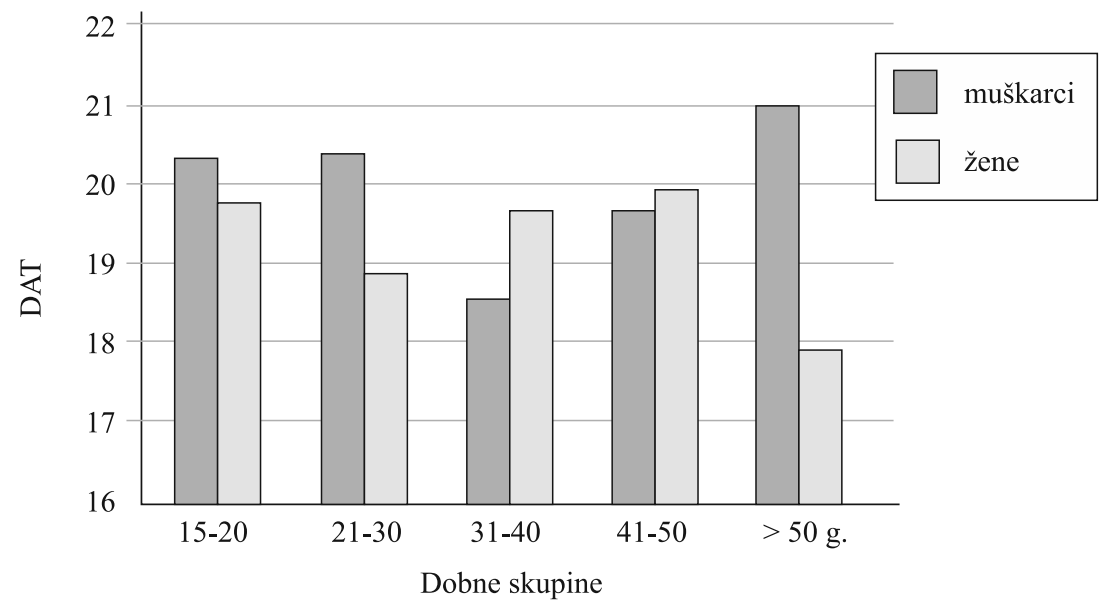

Slika 3. Prikaz prosječnih vrijednosti rezultata na testu verbalnog rasuđivanja s obzirom na dob i spol sudionika $(N=500)$ 
Tablica 6. Značajnost razlika između rezultata dobivenih na testu DAT-verbalno rasuđivanje (DAT-VR) s obzirom na dob i spol sudionika $(N=500)$

\begin{tabular}{lccc}
\hline CTI & $d f$ & $F$ & $p$ \\
\hline Spol & 1 & 2,70 & 0,101 \\
Dob & 4 & 0,48 & 0,751 \\
spol $\times$ dob & 4 & 2,67 & 0,032 \\
\hline
\end{tabular}

Slika 3 prikazuje kako prosječne vrijednosti rezultata sudionika postignute na Testu verbalnog rasuđivanja (DAT-VR) nejednako variraju po dobnim skupinama. U Tablici 6 vidljivo je da nema značajnih razlika u rezultatima na testu verbalnog rasuđivanja s obzirom na spol i dob. To je očekivano s obzirom na to da je sposobnost verbalnog rasuđivanja stabilnija, odnosno ne smanjuje se značajnije s dobi, kao što je to slučaj s neverbalnim sposobnostima. Vidljiva je značajna interakcija spola i dobi, ali Scheffeov test (Prilog 1) ne pokazuje razlike u prosječnim vrijednostima rezultata postignutih na Testu verbalnog rasuđivanja (DAT-VR) s obzirom na spol unutar određenih dobnih skupina, niti s obzirom na dob između pojedinih dobnih skupina.

Utvrđivanje odnosa među rezultatima s obzirom na različite dobne skupine

Ideja da se emocionalna inteligencija može razvijati u funkciji dobi i iskustva pojedinca, uz razvojne promjene u verbalnim i neverbalnim intelektualnim sposobnostima te spolnim razlikama, otvara mogućnost za istraživanja povezanosti rezultata odabranih varijabli s obzirom na različite dobne skupine sudionika. Kao što je vidljivo u nastavku, korelacije unutar dobnih skupina različite su u odnosu na korelacije na cijelom uzorku sudionika (tablice 7 i 8).

Dob je u skupini sudionika od 15 do 20 godina umjereno pozitivno povezana $\mathrm{s}$ mjerama neverbalne $(\mathrm{r}=0,40)$ i verbalne inteligencije $(\mathrm{r}=0,39)$. Povezanost MSCEIT-a i spola je značajna; djevojke postižu bolje rezultate od mladića na mjerama EI (Tablica 7). U dobnoj skupini od 21 do 30 godina značajna je povezanost između verbalne i neverbalne mjere intelektualnih sposobnosti $(r=0,66)$. Uzorak sudionika u dobi od 31 do 40 godina pokazuje ponešto drugačije trendove, naime tu je dobivena značajna negativna povezanost neverbalne inteligencije i mjera emocionalne inteligencije (CTI i MSCEIT). Ponovno je značajna povezanost emocionalnih kompetencija i spola u korist žena, no nešto je niža nego u prethodnim dobnim skupinama, što znači da se s dobi navedene razlike smanjuju. 
Tablica 7. Korelacije između ispitivanih varijabli na uzorcima sudionika u tri dobne skupine (od 18 do 40 godina)

\begin{tabular}{|c|c|c|c|c|c|}
\hline & \multicolumn{5}{|c|}{ Uzorak od 15 do 20 godina $(N=100)$} \\
\hline & CTI & DAT & EI & Spol & Dob \\
\hline CTI & 1 & & & & \\
\hline DAT & $0,57^{*}$ & 1 & & & \\
\hline EI & 0,16 & 0,12 & 1 & & \\
\hline Spol & 0,02 & $-0,06$ & $0,41^{*}$ & 1 & \\
\hline \multirow[t]{3}{*}{ Dob } & $0,40^{*}$ & $0,39 *$ & 0,10 & 0,01 & 1 \\
\hline & \multicolumn{5}{|c|}{ Uzorak od 21 do 30 godina $(N=101)$} \\
\hline & CTI & DAT & EI & Spol & Dob \\
\hline CTI & 1 & & & & \\
\hline DAT & $0,66^{*}$ & 1 & & & \\
\hline EI & 0,05 & $-0,10$ & 1 & & \\
\hline Spol & $-0,19$ & $-0,13$ & $0,45^{*}$ & 1 & \\
\hline \multirow[t]{3}{*}{ Dob } & $-0,12$ & $-0,14$ & 0,17 & 0,17 & 1 \\
\hline & \multicolumn{5}{|c|}{ Uzorak od 31 do 40 godina $(N=94)$} \\
\hline & CTI & DAT & EI & Spol & Dob \\
\hline CTI & 1 & & & & \\
\hline DAT & $0,60 *$ & 1 & & & \\
\hline EI & $-0,30^{*}$ & $-0,10$ & 1 & & \\
\hline Spol & $-0,11$ & 0,13 & $0,26^{*}$ & 1 & \\
\hline Dob & $-0,14$ & $-0,09$ & 0,07 & $-0,02$ & 1 \\
\hline
\end{tabular}

$* p<, 05$

U Tablici 8 vidljive su slične povezanosti u dobnoj skupini od 41 do 50 godina, naročito pozitivna korelacija između mjera neverbalne i verbalne inteligencije, dok se kod sudionika starijih od 50 godina ta povezanost smanjuje. U istoj skupini po prvi put se pojavljuje negativna povezanost fluidne inteligencije i dobi, za razliku od najmlađe dobne skupine $u$ kojoj je ta povezanost pozitivnog smjera $(r=0,40)$. To upućuje na opadanje fluidne inteligencije, za razliku od verbalne inteligencije koja ostaje sačuvana. Dobivena je i značajna povezanost između rezultata postignutih na mjerama neverbalne i emocionalne inteligencije $(\mathrm{r}=0,32)$, odnosno bolji učinak na mjeri fluidne inteligencije u promatranoj dobnoj skupini povezan je s postizanjem boljih rezultata na testu emocionalne inteligencije. Povezanost EI i dobi ide u korist starijih dobnih skupina, dok su žene na mjeri sposobnosti verbalnog rasuđivanja u prosjeku postizale niže rezultate od muškaraca. Općenito, dobivene su negativne povezanosti svih promatranih varijabli u odnosu na dob sudionika kod najstarije dobne skupine. 
Tablica 8. Korelacije između ispitivanih varijabli na uzorcima sudionika u dvije dobne skupine (od 41 godine na dalje)

\begin{tabular}{|c|c|c|c|c|c|}
\hline & \multicolumn{5}{|c|}{ Uzorak od 41 do 50 godina $(N=106)$} \\
\hline & CTI & DAT & EI & Spol & Dob \\
\hline CTI & 1 & & & & \\
\hline DAT & $0,57 *$ & 1 & & & \\
\hline EI & 0,17 & 0,16 & 1 & & \\
\hline Spol & $-0,18$ & 0,02 & 0,17 & 1 & \\
\hline \multirow[t]{3}{*}{ Dob } & $-0,19$ & 0,06 & $-0,02$ & $-0,00$ & 1 \\
\hline & \multicolumn{5}{|c|}{ Uzorak stariji od 51 godine $(N=106)$} \\
\hline & CTI & DAT & EI & Spol & Dob \\
\hline CTI & 1 & & & & \\
\hline DAT & $0,36^{*}$ & 1 & & & \\
\hline EI & $0,32 *$ & 0,10 & 1 & & \\
\hline Spol & $-0,00$ & $-0,34^{*}$ & 0,18 & 1 & \\
\hline Dob & $-0,36^{*}$ & $-0,20$ & $-0,39 *$ & $-0,05$ & 1 \\
\hline
\end{tabular}

${ }^{*} p<, 05$

\section{RASPRAVA}

Da bismo odredili, ali i lakše objasnili i razumjeli emocionalnu inteligenciju, potrebno je povezati područje emocija s kognitivnim sposobnostima. Emocionalnu inteligenciju možemo promatrati kao skup sposobnosti koje bi trebale doprinijeti točnijoj procjeni i izražavanju vlastitih emocija, kao i procjeni tuđih emocija i korištenju emocija na području motivacije, planiranja i postizanja ciljeva u svim područjima života. Kao što je navedeno u uvodu, pojava konstrukta emocionalne inteligencije jedan je od pokušaja pronalaženja mentalnih procesa koji su uključeni u obradu emocionalnih informacija, što bi nadalje omogućilo njihovo sustavno istraživanje. Jedna od specifičnosti vezanih uz emocionalnu inteligenciju koja svakako pridonosi interesu za ovaj konstrukt jest pretpostavka da se, za razliku od klasične, emocionalna inteligencija može razvijati.

Kod starijih osoba, za razliku od adolescenta i osoba mlađe dobi, očekivani su viši rezultati na mjeri emocionalne inteligencije kao sposobnosti, posebno na složenijim granama koje se kasnije razvijaju. Slične varijacije kroz dob se očekuju i $\mathrm{s}$ verbalnim faktorom inteligencije. Pretpostavka da se emocionalna inteligencija razvija u funkciji dobi i iskustva osobe nije bila obuhvaćena u mnogim istraživanjima, a pokazala se kao vrlo bitna osnova za primjenu različitih intervencijskih programa za razvoj emocionalne inteligencije. Najčešće se radilo o istraživanjima koja su provedena na djeci i adolescentima (npr. Ivanović, 2008; Vučenović, 2009) te se samo unutar tih skupina zaključivalo o porastu emocionalne inteligencije s 
porastom dobi. Jedan dio ispitivanja je proveden samo na dvije skupine ispitanika odnosno uspoređivane su grupe mlađe i starije dobi (npr. Leclerc i Kensinger, 2011). Ovim istraživanjem nastojalo se utvrditi da li emocionalna inteligencija raste u funkciji dobi i iskustva pojedinca. Nadalje, provjeravala se hipoteza o emocionalnoj inteligenciji kao sposobnosti, kroz utvrđivanje odnosa s mjerom verbalnih i neverbalnih sposobnosti te utvrđivanja promjena njihovih relacija s obzirom na dob i spol ispitanika.

Kao što je očekivano prema navedenim teorijama i rezultatima prijašnjih istraživanja, i u ovom istraživanju dokazano je kako neverbalne sposobnosti opadaju s dobi, ali u isto vrijeme postoji određena povezanost između rezultata na neverbalnoj i neverbalnoj mjeri inteligencije. Tendenciju smanjivanja neverbalnih intelektualnih sposobnosti s dobi potvrdila su i druga istraživanja (npr. Kaufman, 2001), a dobivenu povezanost je predvidio i sam Cattell (1980), tvorac jedne od najpoznatijih teorija inteligencije, koji navodi kako kristalizirana i fluidna inteligencija pozitivno koreliraju. Isto je potvrđeno i u ranijim domaćim istraživanjima (npr. Šepec, 2007).

Sposobnost emocionalne inteligencije se pokazala višom kod žena nego kod muškaraca i u ranijim istraživanjima (Brackett, Mayer i Werner 2004; Vučenović, 2009; 2012). Generalno, muškarci imaju nižu sposobnost percepcije emocija i manje su skloni uporabi emocija u mišljenju i donošenju odluka. Rezultati ovog istraživanja potvrđuju kako je emocionalna inteligencija razvijenija kod sudionika iz starijih dobnih skupina, slično kao i kristalizirana inteligencija, odnosno verbalni faktor inteligencije. Činjenica kako EI raste s dobi te iskustvom, uz korelacije s kognitivnim i verbalnim sposobnostima, potvrđuje stajalište pristupa emocionalnoj inteligenciji kao sposobnosti.

Analiza razlika u rezultatima na testu emocionalne inteligencije (MSCEIT) s obzirom na spol i dob sudionika pokazala je kako žene postižu bolje rezultate od muškaraca, kao i to da stariji sudionici postižu više rezultate od mlađih, kao što je i očekivano s obzirom na ranija istraživanja (LabouvieVief i Diehl, 2000; Mihaljević, 1999). Bolja emocionalna percepcija u starijoj dobi pomaže da osobe učinkovitije odvoje emocionalne interpretacije od objektivnih aspekata situacije. Dobne razlike povezane su i s kognitivnim predrasudama budući da starije osobe daju prioritet pozitivnim informacijama $u$ odnosu na neutralne i negativne informacije (Scheibe i Carstensen, 2010), zbog čega pronalaze pozitivne aspekte u svakodnevnim životnim situacijama, što je jedan od vidova EI. Razlike u emocionalnoj inteligenciji djelomično objašnjavaju rani socijalizacijski procesi, odnosno različita očekivanja te roditeljski pristup odgoju. Naime, zahtjevi za kontrolom emocionalne ekspresije veći su kod dječaka (Brody i Hall, 1993), dok roditelji češće razgovaraju o emocijama s djevojčicama, čime razvijaju ne samo njihove verbalne već i emocionalne sposobnosti. Navedene razlike objašnjavaju i određeni biološki faktori kao što je bolja povezanost lijeve i desne hemisfere mozga kod žena, što pomaže u verbalnom izražavanju (Jessel i Moir, 1995). 
Provedenim istraživanjem utvrđene su značajne razlike između rezultata postignutih na Cattellovu testu inteligencije s obzirom na spol i dob sudionika. Ukratko, mlađi sudionici u prosjeku su postizali bolje rezultate na testu od starijih sudionika, dok su muškarci postizali bolje rezultate od žena. Dodatne analize ne pokazuju razlike s obzirom na spol unutar različitih dobnih skupina. Također, na testu verbalnog rasuđivanja nisu utvrđene razlike s obzirom na spol ili dob sudionika. Objašnjenje dobnih razlika na neverbalnim testovima odnosi se na razvojni tijek neverbalnih sposobnosti koje opadaju nakon 20-ih godina, dok su verbalne na vrhuncu oko 50ih (Kaufman, 2001). Usto, opće usporavanje središnjeg živčanog sustava u podlozi je opadanja u kognitivnoj izvedbi povezanog s dobi, zbog čega se odrasli sve više oslanjanju na vlastito znanje te iskustvo, odnosno kristaliziranu inteligenciju (Salthouse, 1996).

U ovom istraživanju utvrđena je značajna povezanost između rezultata na neverbalnom testu inteligencije i dobi te između verbalnog testa inteligencije i dobi, ali postoje određene razlike po dobnim skupinama. Mladići su postigli značajno bolje rezultate na testovima neverbalne inteligencije u funkciji porasta dobi (od 15 . do 20. godine), dok su djevojke bolje na mjerama verbalne sposobnosti. Općenito, djevojčice su naprednije u ranom razvoju rječnika od dječaka (Fenson i sur., 1994), pa i u adolescenciji nastavljaju postizati više rezultate na testovima općih verbalnih sposobnosti. Ono što je također utvrđeno jest kako djevojke u toj dobnoj skupini (15-20) postižu bolje rezultate od muškaraca na mjeri emocionalne inteligencije. Potrebno je dodati kako u ovoj dobnoj skupini mišljenje postaje apstraktnije, što olakšava razumijevanje emocija.

U dobnoj skupini od 21 do 30 godina dobivena je značajna povezanost između verbalnih i neverbalnih sposobnosti, moguće zato što fluidna inteligencija još nije počela značajnije opadati dok kristalizirana i dalje raste. U ovoj dobnoj skupini razvijaju se novi, kvalitativno različiti oblici mišljenja, a životni izazovi potiču fleksibilniji način razmišljanja. Nastavljaju se kognitivne razvojne promjene, mišljenje postaje sve fleksibilnije i pragmatičnije. Razlike unutar dobne skupine nisu značajne, moguće zato što razvojne promjene prestaju biti skokovite upravo u mlađoj odrasloj dobi. Unutar ove dobne skupine, povezanost spola i rezultata na MSCEIT-u također je značajna i ponovno žene postižu bolje rezultate od muškaraca.

Što se tiče dobne skupine od 31 do 40 godina, dobivene su značajne negativne povezanosti između rezultata CTI-a i MSCEIT-a. Odrasla dob je vrijeme postizanja naprednog znanja u određenom području (ekspertize), što razvija kreativnost i mišljenje. Stručnost utječe na obradu informacija i unapređuje rješavanje problema u dobi kada propadaju moždane strukture, a neverbalna inteligencija slabi. Suprotno tome, mentalne sposobnosti koje se oslanjaju na kristaliziranu inteligenciju, što je $\mathrm{u}$ ovom istraživanju reprezentirano mjerom emocionalne inteligencije, $\mathrm{s}$ vremenom rastu te povremeno mogu nadoknaditi gubitke u fluidnoj inteligenciji. Upravo su tridesete razdoblje $u$ kojem dolazi do opadanja fluidne inteligencije koja je u podlozi neverbalnih sposobnosti, dok s iskustvom jačaju emocionalne kompetencije, slično 
kao i kristalizirana inteligencija. Korelacija između MSCEIT-a i spola je značajna, ali niža nego kod mlađih sudionika. Moguće da se s dobi smanjuju spolne razlike u mjerama emocionalne inteligencije, kako muškarci stječu više emocionalnog iskustva i preuzimaju nove uloge (npr. očinstvo) te s obzirom na stabilnost i promjene u crtama ličnosti. Slično je vidljivo i u dobnoj skupini od 41 do 50 godina, gdje se rezultati na testu emocionalne sposobnosti muškarca i žena izjednačavaju. $U$ toj dobi jačaju usmjerenost na osobni smisao života, samoprihvaćanje i autonomija. Žene razvijaju maskuline osobine (James, Lewkowicz, Libhaber i Lachman, 1995) zbog čega postaju sigurnije u sebe i direktnije, dok muškarci postaju emocionalniji, empatičniji i manje agresivni. Na taj način moguće je djelomično nadoknaditi rane socijalizacijske utjecaje koji potiču razlike u sposobnosti EI.

Posebno su zanimljive dobivene povezanosti unutar dobne skupine koja je obuhvaćala sudionike iznad 50 godina. Za razliku od svih drugih skupina, u ovoj rezultati upućuju na smanjivanje povezanosti između verbalnih i neverbalnih sposobnosti. Također je značajna i negativna povezanost fluidne inteligencije i dobi, dok kod verbalne inteligencije nije zabilježena značajna povezanost s dobi. Nalazi su očekivani jer se brzina kognitivnog procesiranja koja je u podlozi neverbalnih sposobnosti smanjuje s dobi, a za to su uglavnom odgovorne biološke promjene $\mathrm{u}$ mozgu. Sa stajališta teorije gubitka informacija, svaka informacija pregledava se i interpretira duže, što usporava kognitivni sustav. Zbog toga dolazi do većeg gubitka informacija tijekom njihove obrade. Složeni zadaci su pod jačim utjecajem opadanja (Myerson, Hale, Wagstaff, Poon i Smith, 1990), no vježba i iskustvo (znanje) mogu kompenzirati pogoršanja u brzini obrade. Negativna korelacija između neverbalne inteligencije i dobi sudionika očekivana je zbog pada intelektualnih sposobnosti, odnosno individualne razlike u kognitivnom funkcioniranju veće su u kasnoj nego u bilo kojoj drugoj životnoj dobi. Osim bioloških faktora, za to su odgovorne i aktivnosti slobodnog vremena, od kojih neke pospješuju, a druge ugrožavaju kognitivne sposobnosti. Ograničenost radnog pamćenja otežava dosjećanje, dok prepoznavanje i implicitno pamćenje ostaju relativno dobro sačuvani. Starije osobe biraju svoje aktivnosti na način da optimiziraju (maksimaliziraju) dobiti od energije koju su uložili, a u isto vrijeme pokušavaju kompenzirati gubitke.

Također, u ovoj dobnoj skupini uočena je značajna povezanost neverbalne i emocionalne inteligencije, slično kao i u ranijim istraživanjima (LabouvieVief i Diehl, 2000). Stupanj očuvanosti neverbalnih sposobnosti i apstraktnog mišljenja pomaže starijim osobama da budu u kontaktu sa svojim emocijama te razumiju vlastite pristranosti i često interpretiraju negativne događaje u pozitivnom svjetlu, odnosno postaju bolji u emocionalnoj samoregulaciji (Lawton, 2001). To doprinosi samoprihvaćanju i postizanju ego-integriteta, što je važan razvojni zadatak u toj dobi. Richter i Kunzmann (2011) navode kako starije osobe više govore o emocijama i izražavaju empatiju, te pokazuju manje autonomnih reakcija na emocionalne podražaje (Tsai, Levenson i Carstensen, 2000), odnosno s dobi se smanjuje emocionalna reaktivnost, što omogućava donošenje emocionalno "mudrih" odluka. 
Zaključno, istraživanje je pokazalo kako postoji značajna povezanost varijabli emocionalne inteligencije te spola i dobi sudionika. Zatim, dob je povezana s višim rezultatima mjerenja emocionalne inteligencije, a negativno s mjerama neverbalne inteligencije. Ključni nalaz odnosi se na pozitivnu povezanost dobi i rezultata na mjeri emocionalne inteligencije, posebno na složenijim granama. Rezultati se uklapaju u pretpostavke pristupa ispitivanju emocionalne inteligencije testovima uratka u kojima je poznato "točno" rješenje, jer se pretpostavlja kako je to sposobnost slična ostalim kognitivnim sposobnostima. Budući da se razvija s dobi te iskustvom, a rezultati pokazuju značajne umjerene korelacije s mentalnim sposobnostima (naročito verbalnim), time su zadovoljeni kriteriji u korist definiranja emocionalne inteligencije kao sposobnosti.

Zbog ograničenja transverzalnog nacrta istraživanja, širokog raspona kronološke dobi ispitanika i relativno niskih povezanosti, navedene tvrdnje treba uzeti s dozom opreza. Raspon dobi ispitanika može utjecati na niže koeficijente povezanosti među varijablama, a većim brojem ispitanika sigurno bi se stabilizirali različiti utjecaji na varijacije rezultata promatranih varijabli. Ograničenja se odnose i na rezultate sudionika u starijoj dobnoj skupini, s obzirom na pitanje (ne)prilagođenosti instrumenata za mjerenje emocionalne inteligencije njihovoj dobi. To se odnosi prvenstveno na sadržaj zadataka koji su prilagođeni mlađim dobnim skupinama, na kojima su testovi najčešće konstruirani i validirani, a za ispitanike starije dobi mogu imati drugačije značenje ili ne biti relevantni za njihovu dob. Poteškoću u ovom istraživanju predstavljalo je i određivanje točnog odgovora na MSCEIT-u, odnosno njegovo bodovanje. Budući da za emocionalne informacije ne postoji apsolutni algoritam prema kojem se može odrediti točan odgovor, često se točan odgovor određuje na temelju slaganja s ostatkom grupe. Ograničenje metode konsenzusa na širokom rasponu dobi ispitanika su velika odstupanja od točnog odgovora, posebno kod mlađih i starijih ispitanika. Da bi se izbjegao taj problem u budućim istraživanjima, možda bi opravdanije bilo odrediti konsenzus s obzirom na pojedinu dobnu skupinu. Konačno, daleko preciznije rezultate i širu sliku moguće je dobiti jedino praćenjem individualnih razlika u razvoju i ispitivanja odnosa između ranijih i kasnijih događanja i ponašanja. Navedeni problem mogao bi se riješiti primjenom longitudinalnog nacrta istraživanja, koji se nažalost ne primjenjuje često zbog svoje dugotrajnosti i ostalih dobro poznatih nedostataka.

\section{LITERATURA}

Brackett, M. A., Mayer, J. D. i Werner, R. M. (2004). Emotional intelligence and its relation to everyday behavior. Personalitiy and Individual Differences, 36, 1387-1402.

Brody, R. i Hall, A. J. (1993). Gender and Emotion. U: Michael Lewis and Jeannette Haviland (ur.). Handbook of Emotions (str. 369-393). New York: Guilford Press. 
Cattell, R. B. (1980). The heritability of fluid, gf, crystallized, gc, intelligence, estimated by least squares use of the Mava method. British Journal of Educational Psychology, 50, 223-265.

Cattell, R. B. (2000). Mjerenje inteligencije Cattellovim testovima inteligencije: priručnik za ljestvice 2 i 3 . Jastrebarsko: Naklada Slap.

Cauffman, E., Shulman, E. P., Steinberg, L., Claus, E., Banich, M. T., Graham, S., Woolard, J. (2010). Age differences in affective decision making as indexed by performance on the Iowa Gambling Task. Developmental Psychology, 46 (1), 193-207.

Fenson, L., Dale, P. S., Reznick, J. S., Bates, E., Thal, D. J., i Pethick, S. J. (1994). Variability in early communicative development. Monographs of the Society for Research in Child Development, 59 (5), 174-185.

Goleman, D. (1997). Emocionalna inteligencija. Zagreb: Mozaik knjiga.

Hyde, G. i Trickey, G. (2005). Priručnik diferencijalnih sposobnosti DAT za profesionalno usmjeravanje i selekciju. Jastrebarsko: Naklada Slap.

Ivanović, M. (2008). Emocionalna inteligencija, empatija i agresivno ponašanje u ranoj adolescenciji. Diplomski rad. Filozofski fakultet. Zagreb.

James, J. B., Lewkowicz, C., Libhaber, J., i Lachman, M. (1995). Rethinking the gender identity crossover hypothesis: A test of a new model. Sex Roles, 32, 185-207.

Jessel, D. i Moir, A. (1995). Muški pol, ženski pol. Zagreb: Izvori Tiskara.

Kaufman, A. S. (2001). WAIS-III IQs, Horn's theory, and generational changes from young adulthood to old age. Intelligence, 29, 131-167.

Kulenović A., Balenović T. i Buško V. (2001). Test analize emocija: jedan pokušaj objektivnog mjerenja sposobnosti emocionalne inteligencije. Suvremena psihologija, 3, 27-48.

LabouvieVief, G., i Diehl, M., (2000). Cognitive complexity and cognitive-affective integration: Related or separate domains of adult development? Psychology and Aging, 15, 409-504.

Lawton, M. P., (2001). Emotion in later life. Current Directions in Psychological Science, 10, 120-123.

LeClerc, C. M. i Kensinger, E. A. (2011). Neural processing of emotional pictures and words: A comparison of young and older adults. Developmental Neuropsychology, 36 (4), 519-538.

Lopez, P. N., Salovey, P. i Straus, R. (2003.), Emotional intelligence, personality, and the perceived quality of social relationship. Personality and Individual Differences, 35, 641-658.

Mayer, J. D. i Salovey, P. (1997). What is emotional intelligence? U: P.Salovey i D. Sluyter (ur.). Emotional development and emotional intelligence: Implications for educators (str. 3-31). New York: Basic Books.

Mayer, J. D., Salovey, P., Caruso, D. i Sitarenios, G. (2003). Measuring emotional intelligence with the MSCEIT v2.0. Emotion, 3, 97-105.

Mayer, J. D., Salovey, P. i Caruso, D. R. (2002). TheMayer-Salovey-Caruso Emotional Intelligence Test (MSCEIT) Technical manual. Toronto: Multi-Health Systems.

Mihaljević, S. (1999). Emocionalna inteligencija i njen odnos s nekim interpersonalnim značajkama. Diplomski rad. Filozofski fakultet u Zadru. 
Myerson, J., Hale, S., Wagstaff, D., Poon, L. W. i Smith, G. A. (1990). The information-loss model: A mathematical theory of age related cognitive slowing. Psychological Review, 97, 475-487.

Petrides, K. V. i Furnham, A. (2000). On the dimensional structure of emotional intelligence. Personalitiy and Individual Differences, 29, 313-320.

Richter, D. i Kunzmann, U. (2011). Age diferences in three facets of empathy: performance based evidence. Psychology and aging, 26 (1), 60-70.

Roberts, R. D., Zeidner, M. i Matthews, G. (2001). Does Emotional Intelligence Meet Traditional Standards for an Intelligence? Some New Data and Conclusions. Emotion, 1 (3), 196-231.

Salthouse, T. A. (1996). Constraints of theories of cognitive aging. Psychonomic Bulletin and Review, 3, 287-299.

Scheibe, S. i Carrstensen, L. L. (2010). Emotional aging: Recent findings and future trends. Journal of Gerontology: Psychological Sciences, 65, 135-144.

Slaski, M. i Cartwright, S. (2003). Emotional intelligence training and its implications for stress, health and performance, Stress and Health, 19, 233-239.

Šepec, T. (2007). Provjera nekih psihometrijskih karakteristika tri testa sposobnosti DAT baterije u selekcijskoj proceduri. Diplomski rad. Filozofski fakultet. Zagreb.

Takšić, V., Mohorić, T. i Munjas, R. (2006). Emocionalna inteligencija: teorija, operacionalizacija, primjena i povezanost s pozitivnom psihologijom. Društvena istraživanja, Vol. 15 No. 4-5 (84-85), 729-752.

Tsai, J. L., Levenson, R. W. i Carstensen, L. L. (2000). Autonomic, subjective, and expressive responses to emotional films in older and younger Chinese Americans and European Americans. Psychology and Aging, 15, 684-693.

Vučenović, D. (2009). Emocionalna inteligencija, stilovi roditeljskog odgoja i depresivnost kod adolescenata. Magistarski rad. Filozofski fakultet: Zagreb.

Vučenović, D. (2012). Emocionalna inteligencija i obrada emocionalnih sadržaja u različitoj dobi. (Neobjavljen doktorski rad). Filozofski fakultet: Zagreb.

Vučenović D. (2015a). Emocionalna inteligencija i emocionalna pismenost. U: Marković, N. (ur). Komunikacija odgaja-odgoj komunicira: emocionalna i medijska pismenost (str. 10-20). Zagreb: Pragma.

Vučenović, D., Hajncl, Lj., Takšić, V. (2015b). Razvoj emocionalne inteligencije u obiteljskom okruženju i odnos s problemima u ponašanju. U: Brajša-Žganec, A., Lopižić, J. i Penezić, Z. (ur). Psihološki aspekti suvremene obitelji, braka i partnerstva (str. 275297). Naklada Slap i Hrvatsko psihološko društvo. 


\title{
EFFECTS OF AGE ON THE RELATIONSHIP BETWEEN VERBAL AND NONVERBAL ABILITIES AND EMOTIONAL INTELLIGENCE
}

\begin{abstract}
Summary
The research aimed to establish the relationship between the results of measurement of emotional intelligence, their relation to the measure of verbal and nonverbal abilities, as well as age and gender of the participants. The study was conducted on a sample of 500 participants with a wide range of chronological age (15 to 65 years, mean 36.9 years) and both genders $(M=257, F=243)$. Significant correlations between emotional intelligence, gender and age of participants were obtained. In other words, women achieve better results than men, and older respondents achieve better results than younger ones. Age is associated with higher results of emotional intelligence, and a negative correlation is established between established intelligence and age: in the elderly, significant lower levels of nonverbal abilities were observed. The key findings relate to the fact that age and experience result in improved results on emotional intelligence, especially in more complex branches such as understanding and emotion analysis, reflexivity and emotional regulation. These results, combined with correlations of the verbal factor of intelligence are in accordance with the understanding of emotional intelligence as an ability, opposed to the standpoint of emotional intelligence as a personality trait that should be measured by self-assessment scales.
\end{abstract}

Keywords: verbal and nonverbal abilities, emotional intelligence.

Primljeno: 15. 10. 2018. 


\section{Prilog 1}

Tablica značajnosti razlika između prosječnih vrijednosti rezultata postignutih na testu verbalnog rasuđivanja (DAT-VR) s obzirom na spol i dob sudionika (Scheffe test; $\mathrm{N}=500$ )

\begin{tabular}{ccccccccccccc} 
VAR & Spol & Dob & M & 1 & 2 & 3 & 4 & 5 & 6 & 7 & 8 & 9 \\
\hline 1 & M & $15-20$ & 20,48 & & & & & & & & & \\
2 & M & $21-30$ & 20,44 & 1,00 & & & & & & & & \\
3 & M & $31-40$ & 18,66 & 0,97 & 0,96 & & & & & & & \\
4 & $\mathrm{M}$ & $41-50$ & 19,90 & 1,00 & 1,00 & 1,00 & & & & & & \\
5 & $\mathrm{M}$ & $>50$ & 21,22 & 1,00 & 1,00 & 0,71 & 0,99 & & & & & \\
6 & $\check{Z}$ & $15-20$ & 19,88 & 1,00 & 1,00 & 1,00 & 1,00 & 0,99 & & & & \\
7 & $\check{Z}$ & $21-30$ & 19,04 & 0,99 & 0,99 & 1,00 & 1,00 & 0,85 & 1,00 & & & \\
8 & $\check{Z}$ & $31-40$ & 19,86 & 1,00 & 1,00 & 1,00 & 1,00 & 0,99 & 1,00 & 1,00 & & \\
9 & $\check{Z}$ & $41-50$ & 20,15 & 1,00 & 1,00 & 0,99 & 1,00 & 1,00 & 1,00 & 1,00 & 1,00 & \\
10 & $\check{Z}$ & $>50$ & 18,15 & 0,82 & 0,79 & 1,00 & 0,96 & 0,38 & 0,96 & 1,00 & 0,97 & 0,90 \\
\hline
\end{tabular}

Prema Scheffeovu testu, kao što se može vidjeti iz Priloga 1, ne postoji nijedna statistički značajna razlika između prosječnih vrijednosti rezultata sudionika postignutih na Testu verbalnog rasuđivanja (DAT-VR) s obzirom na spol niti s obzirom na dob sudionika, kao ni u njihovim međusobnim interakcijama. Na osnovi dobivenih rezultata moglo bi se pretpostaviti da je sposobnost verbalnog rasuđivanja stabilna u funkciji dobi, odnosno ne dolazi do opadanja verbalnih sposobnosti kod sudionika iz različitih dobnih skupina, kao što je to slučaj s prethodno navedenim neverbalnim sposobnostima. 
